\title{
Psychiatric court reports for bail applications
}

\author{
ANN BARKER, Senior Registrar, Broadmoor Hospital, Crowthorne, Berkshire
}

The presence of the Official Secrets Acts of 1911 and 1920 precludes comment from doctors working within Her Majesty's prisons on the state of remand prisons in Britain. Her Majesty's Chief Inspector of Prisons, Judge Tumin, has described them as "intolerable, and representing much human misery". In an article entitled 'Under the prison outrage: a quieter scandal', Kilroy-Silk (1989) refers to a report implying that, at any one time, one third of remand prisoners suffer from mental illness.

Britain is now top of the 'European league for jailings' (Hodges, 1989) at 97.4 people per 100,000 of the population. Whatever the actual proportion of prisoners suffering from mental illness in this country, at any one time between one fifth and one quarter of the entire prison population is composed of men who have not been convicted of the alleged crime. With an ironic tolerance of ambiguity, a nation that takes pride in upholding concepts such as 'innocent until proved guilty', nevertheless continues to detain these very same people in the most squalid of conditions (Morgan, 1989).

The Probation Service is the body most frequently involved in providing court reports, and is currently conducting its own research projects into possible ways of decreasing the prison remand population (Morgan, 1989). Psychiatrists are among the experts next most commonly approached for a court report. Commonly, the request for a psychiatric opinion on a remand prisoner is couched in the form of a question about the defendant's 'fitness to plead'.

'Fitness to plead' is an issue which is ultimately decided by a jury at Crown Court. The legal criteria, discussed by Larkin \& Collins (1989) are straightforward, as demonstrated in the following table:

\section{Criteria for fitness to plead}

\section{$R$ v. Pritchard (1836)}

1. To comprehend the course of proceedings at the trial so as to make a proper defence.

2. To comprehend the details of the evidence.
3. To challenge a juror to whom he might wish to object.

\author{
3. Give adequate \\ instruction to his legal \\ advisers.
}

\section{Plead with understanding to the indictment.}

These criteria could be as easily determined by a solicitor as a psychiatrist (Roesch et al, 1984). The outcome of being found unfit to plead, however, is complex, and includes the fact that a defendant may be detained in hospital indefinitely without ever having been through a trial for the offence. Because of the potentially dire consequences for the patient, and the alternative provisions of the Mental Health Act (1983), the Criminal Procedure (Insanity) Act (1964) is used only a handful of times each year in this country. Larkin \& Collins discuss the merits of the various sections of the Mental Health Act (1983), sections 35,36 and 48 , for transferring a prisoner who is in need of hospital treatment, prior to trial. Alternatively, there is no legal reason why a defendant should not be given bail, and detained in hospital for treatment under either Section 2 or 3 of the Mental Health Act (1983).

Psychiatrists will, inevitably, also be asked to see patients for whom hospital treatment is inappropriate. It appears to me that, in such circumstances, psychiatrists ought to be asking themselves, and checking with the solicitor, whether a report considering the suitability for bail is not part of the remit.

Psychiatrists should be aware that, in distinction to probably all other proceedings in the criminal justice system, which are based on an adversarial system, courts considering the matter of bail are specifically enjoined to adopt an inquisitorial approach. A decision to grant or withhold bail is made in the first instance at the magistrates' court; subsequently, after a case has been committed for trial at Crown Court, an appeal against a decision to remand in custody is made before a judge in chambers. It is a decision that should be made by a court in possession of the maximum amount of information about the defendant.

A psychiatric court report addressing the issue of bail is thus quite different from a report prior to the trial of a not-guilty plea: in this, the most unexpected details may prove prejudicial to the defendant, and 
the least said, the better. It is also different from a report following a conviction or a plea of guilty which is, in essence, part of a plea in mitigation. In considering the matter of bail, the court is not concerned with issues of guilt, innocence, intent or culpability: it is primarily concerned to ensure that the defendant returns to court at a later date for the due process of law to be fulfilled, although it is also concerned that further offences should not be committed during the remand period.

Since the Bail Act (1976), the onus is on the court to grant bail, and if bail is refused, the reason has to be announced publicly. The law and practice relating to repeated applications for bail has been modified (Samuels, 1989). In principle, if a person is in custody, the arguments for and against bail ought to be heard every time he appears in court. In practice, courts cannot be expected to listen to the same arguments time and time again; at the third and subsequent court appearances there is judicial discretion as to whether a further bail application may be allowed, based, in particular, on the emergence of fresh information or a change of circumstances. Such fresh information may be supplied in a psychiatric report.

A court may refuse to grant bail if:

it is considered necessary for the defendant's own protection to keep him in custody

he is already serving a prison sentence for a different offence

he is in breach of a condition of bail

or it has been impractical to obtain sufficient information for a decision about bail to be made.

Recently a requirement has been placed on courts for giving the reasons if bail is granted in the most serious cases, such as murder or rape (Samuels, 1989). Other than these situations, however, before withholding bail, a court is required to have 'substantial grounds for believing' that the defendant:

would fail to surrender to custody would commit an offence while on bail or would interfere with witnesses or otherwise obstruct the course of justice.

'Substantial grounds for believing' that one of the reasons exists should clearly, in theory, be based on a detailed knowledge of the defendant. When providing a psychiatric report, the factors which will be of particular relevance to a bail decision and which will influence the court include an outline of:

the nature and seriousness of the offence. If it is an offence that is likely to attract a custodial sentence, the court's reason for a remand in custody is - not to administer a dose of punishment prior to trial - but to ensure that the defendant does not take fright and abscond. 'the character, antecedents, associations and community ties' of the defendant: that is, in effect, features of the defendant that indicate his stability, reliability and likelihood of remaining in one place up to the time of trial, such as the availability of accommodation or work, or a record of reliable attendance while on probation or attendance at Outpatients. The 'antecedents' - or previous criminal convictions - are important in weighing the likelihood of further offences occurring during the period of bail; in the eyes of the court, a man with frequent previous convictions is unlikely to break the offending habit merely because of the imminence of yet another court case.

his previous record in fulfilling bail conditions, such as attending court on the right day, observing any curfew or residing at an approved address.

the strength of the evidence against him. With the issue of false and retracted confessions very much in the air (Gudjonsson \& MacKeith, 1988), note should be made in particular of whether the defendant was in any way vulnerable through mental illness, handicap, or physical illness at the time of police interview, and whether he was interviewed by the police in the presence of his solicitor, or another 'reliable adult'. For those who are 'vulnerable', there should be some external corroborating evidence. A court considering a bail application is concerned with this issue because, if the defendant is ultimately acquitted, he will have spent time in custody for no good reason and without any means of redress for his loss of liberty.

Clearly, with the more serious offences, some of these issues cannot be addressed without having read a copy of the depositions in the case and a copy of the previous criminal record. In individual cases, a copy of the 'custody record', kept by the Police by law under the provisions of the Police and Criminal Records Act (1984), and covering the time of detention in police custody during police interviews, can be helpful. If such information has not already been supplied, it can be requested from the defence solicitor.

In summary, at present nearly a quarter of the prison population in Britain at any one time consists of people technically innocent, awaiting trial. In each case, the court will have made a decision about bail. The decision about bail is open to review by the court in the light of fresh information, or a change of circumstances. Psychiatrists should be aware that they can provide valuable information contributing to a bail decision, and if requested to give an opinion on 'fitness to plead', should also, in my opinion, consider the question of bail. They should, however, be aware that a psychiatric report for this purpose addresses different issues, and that the court has in mind specific questions, which have been outlined above. 


\section{References}

Gudjonsson, G. H. \& MacKeITH, J. A. C. (1988) Retracted confessions: legal, psychological and psychiatric aspects. Medicine Science and the Law, 28, 187-194.

HODGES, L. (1989) Britain top of the European league for jailings. The Daily Telegraph, 31 October 1989.

KILROY-SILK, R. (1989) Under the prison outrage: a quieter scandal. The Times, 27 October 1989.

LARKIN, E. P. \& Collins, P. J. (1989) Fitness to plead and psychiatric reports. Medicine Science and the Law, 29, 26-32.
Morgan, R. (1989) Remands in custody: problems and prospects. The Criminal Law Review, July, 481-492.

Roesch, R., Jackson, M. A., Sollner, R., Eaves, D., Glackman, W. \& Webster, C. D. (1984) The fitness to stand trial interview test: how four professions rate videotaped fitness interviews. International Journal of Law and Psychiatry, 7, 115-131.

Samuels, A. (1989) The new bail law. The Magistrate, 45, 183.

\section{Miscellany}

\section{Honour}

Dr Robyn Hewland of Christchurch, New Zealand, a Fellow of the College, was awarded the Queen's Service Medal for Public Services (QSM) in the New Year Honours List 1990.

\section{Awards}

Dr Timothy Crow, Head of the Division of Psychiatry, Clinical Research Centre, Northwick Park Hospital, Harrow, Middlesex has been awarded the 1989 Lieber Prize. This Prize was established in 1987 by Constance and Stephen Lieber of Mamroneck, New York to honour and recognise long-term outstanding accomplishments in the field of schizophrenia research.

The biennial award in memory of Professor Trevor Gibbens is to be made in November 1990. The Committee responsible for granting the award welcome applications from anyone working with offenders or victims. The award, in the region of $\mathfrak{f 7 0 0}$, is given to the individual or organisation regarded as best able to use it, and applicants are required to state simply the purpose for which the money is needed. Applications may be made for equipment, travel etc. and should be sent to Dr Graham Robertson, Secretary, Trevor Gibbens Award, Institute of Psychiatry, De Crespigny Park, London SE5 8AF, to be received by the end of September 1990.

The Merck awards (total annual value $£ 1500$ ), to be made by the Scottish Division, are open to members of the College working in Scotland who are trainee psychiatrists or are consultants within three years of their first appointment. The award(s) may take the form of a research or travelling grant. Applicants should submit a curriculum vitae, a statement of current interests and planned research or study, and the names of two referees before 30 September 1990 to Dr R. G. McCreadie, Secretary, Scottish Division, Royal College of Psychiatrists, Crichton Royal Hospital, Dumfries DGl 4TG.

\section{New Professorial appointment}

Professor "Izzy" Kolvin has been appointed to a newly created joint Chair between the Tavistock Clinic Child and Family Department and the Royal Free Hospital Medical School. Professor Kolvin, formerly Professor of Child and Adolescent Psychiatry and Director, Human Development Unit, University of Newcastle upon Tyne, took up his appointment in March 1990. The joint Professorship is intended to promote the child and family research programmes of the Tavistock Clinic, and to foster the child psychiatric educational facilities at the Royal Free Hospital Medical School.

\section{New publications}

Psychological Science is the bimonthly journal of the American Psychological Society and is designed to be the forum for research, theory and application in psychology and the closely related behavioural, cognitive, neural and social sciences. There is a $20 \%$ off normal subscription price offer which closes on 30 June 1990: £52 for Institutions (normally £65); $£ 24$ for Individuals (normally $£ 30$ ) and $£ 12$ per single part. Further information: Michael Atkinson, Psychological Science, Cambridge University Press, The Edinburgh Building, Shaftesbury Road, Cambridge CB2 2RU (telephone 0223 325806).

Training on AIDS for Personnel of Drug Treatment Centres, a 27 page WHO publication, is available by mail order from HMSO Publications Centre, 51 Nine Elms Lane, London SW8 5DR. 